\title{
Beyond an Inflamed Ear
}

\author{
Para Além de uma Orelha Inflamada
}

\author{
Cristina PONTE ${ }^{1,2}$, Carla MACIEIRA ${ }^{1}$ \\ Acta Med Port 2014 Nov-Dec;27(6):790-790
}

Keywords: Ear Diseases; Ear, External; Polychondritis, Relapsing.

Palavras-chave: Doenças do Ouvido; Ouvido Externo; Policondrite Recidivante.

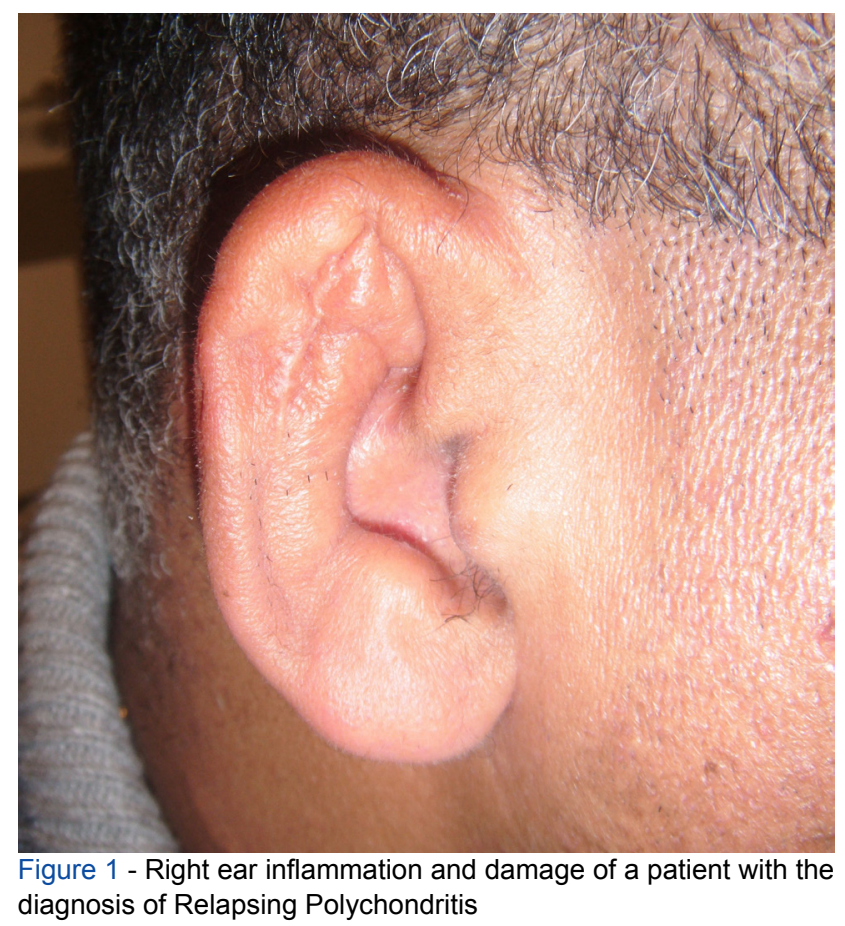

We present a case of a 48 years-old black man who was referred to our Rheumatology outpatient clinic with a 2 years history of recurrent pain, swelling and redness of his right ear (unresponsive to several courses of antibiotics) and an isolated episode of left ear inflammation, with spontaneous resolution, in the previous year.

He had a background history of systemic hypertension, sinusitis and a recently diagnosed episode of right punctate keratitis. He denied fever, joint pain, dysphonia or shortness of breath. His serum inflammatory markers were persistently elevated and his blood cultures were negative. The diagnosis of Relapsing Polychondritis was made. ${ }^{1}$

The patient was started on prednisolone $1 \mathrm{mg} / \mathrm{kg} /$ day and his clinical condition showed rapid and significant improvement. The prednisone was slowly tapered and methotrexate was successfully added as a steroid sparing agent. ${ }^{1,2}$

This case highlights the importance of considering systemic and rare causes for an inflamed ear. ${ }^{3}$

\section{REFERENCES}

1. Yoo JH, Chodosh J, Dana R. Relapsing polychondritis: systemic and ocular manifestations, differential diagnosis, management, and prognosis. Seminars Ophthalmol. 2011;26:261-9.

2. Rapini RP, Warner NB. Relapsing polychondritis. Clin Dermatol. 2006;24:482-5.

3. Kawai H, Nakajima A. Red puffy ears. N Engl J Med. 2010;362:928. 
Cristina PONTE, Carla MACIEIRA

\section{Beyond an Inflamed Ear}

Acta Med Port 2014:27:790-790

Publicado pela Acta Médica Portuguesa, a Revista Científica da Ordem dos Médicos

Av. Almirante Gago Coutinho, 151

1749-084 Lisboa, Portugal.

Tel: +351218428 215

E-mail: submissao@actamedicaportuguesa.com

www.actamedicaportuguesa.com

ISSN:0870-399X | e-ISSN: 1646-0758

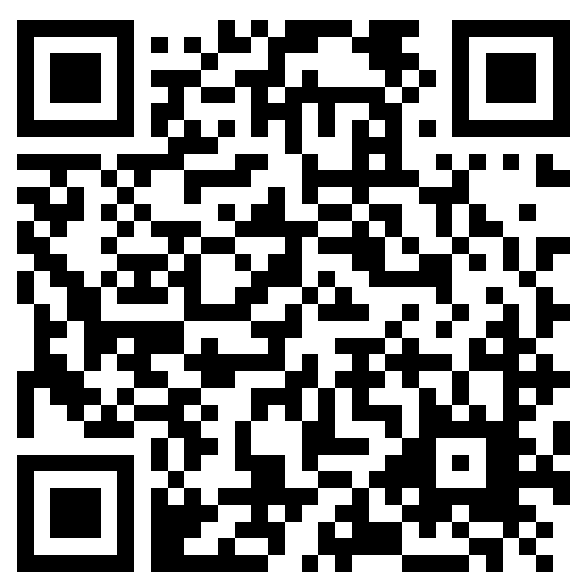

